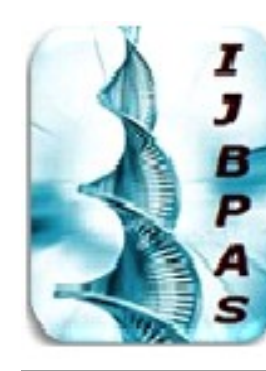

International Journal of Biology, Pharmacy and Allied Seiences (IJBPAS) 'A Bridge Betueen Caboratory and QRendo' WwW.ijbpas.com

IN VITRO CYTOTOXICITY ASSAY, ANTIOXIDANT SCREENING AND HEPATOPROTECTIVE ACTIVITY OF SUCCESSIVE EXTRACTS OF ALYSICARPUS VAGINALIS VAR. NUMMULARIFOLIUS (DC.) MIQ. (FAMILY: FABACEAE) IN HEPG2 CELL LINES

\title{
KURIAN S ${ }^{1 *}$, JOSEPH L ${ }^{1}$ AND JOSEKUMAR VS ${ }^{2}$
}

1: Department of Zoology, Mar Ivanios College (Autonomous), Thiruvananthapuram-695015, Kerala, India

2: Associate Professor, Department of Zoology, Mar Ivanios College (Autonomous), Thiruvananthapuram-695015, Kerala, India

\section{*Corresponding Author: Email:}

*Corresponding Author: Kurian S: E Mail: susan.kurian@mic.ac.in

Received 27 $7^{\text {th }}$ March 2020; Revised $17^{\text {th }}$ April 2020; Accepted $9^{\text {th }}$ July 2020; Available online $1^{\text {st }}$ Jan. 2021 https://doi.org/10.31032/IJBPAS/2021/10.1.5298

\begin{abstract}
The present study aims to screen the in vitro cytotoxicity, antioxidant potential and hepatoprotective activity of hexane (AVH), ethyl acetate (AVE) and methanol (AVM) extracts of Alysicarpus vaginalis var. nummularifolius, which is a traditionally used plant for jaundice. The cytotoxicity screening of different extracts was determined by MTT cell viability assay using L929 normal fibroblast cell lines. Antioxidant potential of plant extracts was studied by ABTS and hydroxyl radical scavenging activity. Total antioxidant capacity was evaluated by phosphomolybdenum method. In vitro hepatoprotective activity of the extracts was evaluated against $\mathrm{CCl}_{4}$ induced toxicity in $\mathrm{HepG} 2$ cell lines. Invitro cytotoxicity study report the $\mathrm{IC}_{50}$ values of hexane, ethyl acetate and methanol extracts of A.vaginalis as $55.26 \mu \mathrm{g} / \mathrm{ml}, 41.51 \mu \mathrm{g} / \mathrm{ml}$ and $112.6 \mu \mathrm{g} / \mathrm{ml}$ respectively. Significant dose dependent increase in percentage viability of HepG2 cells at the dose $6.25,12.5,25,50$ and $100 \mu \mathrm{g} / \mathrm{ml}$ concentration of different extracts compared to $\mathrm{CCl}_{4}(0.1 \%)$ exposed cells. AVM showed high hepatoprotective activity than AVH. AVE
\end{abstract}


showed dose dependent action, lower concentrations give hepatoprotective activity while at higher concentration an inhibitory effect is noticed. Thus the present study shows that methanol extract is non-toxic in nature while hexane and ethyl acetate extract of A.vaginalis are moderately toxic. High antioxidant activity is exhibited by ethyl acetate and methanol extract than the hexane extract. A good hepatoprotective effect is exhibited by the methanol extract than the other two extracts.

Keywords: Alysicarpus vaginalis var. nummularifolius, in vitro cytotoxicity, hepatoprotective activity, antioxidant

\section{INTRODUCTION}

Plant kingdom is the source of phytochemicals that are having broad spectrum of pharmacological activities [1]. Herbal drugs assumed to be safe for treatments in traditional system of medicine are very often identified toxic to vital organs [1]. Hence plants used in traditional medicines should be analyzed for its pharmacological potentiality and possibility of toxicity effects. Free radicals cause various ailments like liver cirrhosis, atherosclerosis, diabetes, cancer etc. [2]. Reactive oxygen species inactivates the enzymes and damage the cellular integrity resulting in injury [3]. Many herbal plants contain antioxidant which can protect the body against these free radicals [4].

Liver diseases create a major problem around the world. The major risk factors of liver diseases are hepatitis, viral infection, toxic chemicals, alcohol etc. Herbal medicines are viable alternative to synthetic drugs [5].

Alysicarpus vaginalis which is commonly known as Alyce clover or one leaf clover, coming under the family Fabacea. Traditionally it is used with goat milk for the treatment of jaundice. It is used in Ayurvedic medicine (Indian traditional system of medicine) and in folk medicine for the treatment of coughs, pulmonary and renal disorders. It is also used for the treatment of diarrhea, Ascariasis and constipation [6].

On the basis of its diversified pharmacological properties and its use in liver disease treatment formulation, the main objective of the present study was to screen the hepatoprotective activity of the various extracts of A.vaginalis against $\mathrm{CCl}_{4}$ toxicity in HepG2 cell lines.

\section{MATERIALS AND METHODS}

\section{Collection of Plant Materials}

Alysicarpus vaginalis var. nummularifolius (DC.) Miq. was collected from Nalanchira, Thiruvananthapuram, Kerala, India. It is a 
common creeping herb found in open ground and waste land and is widely distributed in India, Sri Lanka, Pakistan, Africa and Australia. The leaves are obovate -oblong, obtuse at both ends and having a diameter of 1-2.5 cm. Its flowers are pink in dense recemes. They flower and fruit during the month of September to January. The plant specimen was authenticated by Dr. G. Valsaladevi, Curator, Department of Botany, University of Kerala, Kariavattom, Thiruvananthapuram, Kerala and the voucher specimen has been deposited in the Herbarium of Department of Botany, University of Kerala with voucher no KUBH -5928 for future reference.

\section{Preparation of the plant Extracts}

The entire fresh plant materials were collected washed and shade dried. The dried plant materials were grinded to fine powder using an electric grinder. The dried and powdered plant material was successively extracted with hexane (AVH), ethyl acetate (AVE) and methanol (AVM) in the order of their increasing polarity in soxhlet apparatus until it became colourless according to the standard methods [7]. Each extract was concentrated by using rotary vacuum evaporator (Buchi Rotavapor) and stored in refrigerator for further analysis.

Invitro cytotoxicity study on L929 cell lines

\section{Cell lines -Its culture}

L929 (normal mouse fibroblast) cells were obtained from NCCS, Pune, India and maintained in Dulbecos modified Eagles medium. The cell lines were cultured with DMEM supplemented with $10 \%$ Foetal Bovine Serum (FBS) and was kept at $37^{\circ} \mathrm{C}$ in a humidified $5 \% \quad \mathrm{CO}_{2}$ incubator (New Brunswick Scientific, Eppendorf, Germany).

\section{MTT Assay}

L929 cells were seeded in triplicate in 96-well microplates and kept at $37^{\circ} \mathrm{C}$ in $5 \%$ $\mathrm{CO}_{2}$ incubator. After $24 \mathrm{~h}$, the cells were treated with different concentrations of plant extracts $(6.25,12.5,25,50 \& 100 \mu \mathrm{g} / \mathrm{ml})$. Cells without plant extracts were used as negative control.

The viability of cells were evaluated by direct observation of cells by inverted phase contrast microscope and followed by MTT assay.

The percentage of growth inhibition was calculated using the formula:

$$
\% \text { of viability }=\frac{\text { Mean OD Samples } x \quad 100}{\text { Mean OD of control group }}
$$

\section{Antioxidant activity \\ Hydroxyl radical scavenging activity \\ The scavenging capacity for hydroxyl radical was measured according to the modified method of Halliwell et al., (1987) [8]. Stock solutions of EDTA (1 mM), $\mathrm{FeCl}_{3}(10 \mathrm{mM})$,}


Ascorbic Acid $(1 \mathrm{mM}), \mathrm{H}_{2} \mathrm{O}_{2}(1 \mathrm{mM})$ and Deoxyribose $(10 \mathrm{mM})$, were prepared in distilled deionized water.

The assay was performed by adding $0.1 \mathrm{ml}$ EDTA, $0.01 \mathrm{ml}$ of $\mathrm{FeCl}_{3}, 0.1 \mathrm{ml} \mathrm{H} \mathrm{O}_{2}, 0.36$ $\mathrm{ml}$ of deoxyribose, $1.0 \mathrm{ml}$ of the extract of different concentration $(125,250,500 \&$ $1000 \mu \mathrm{g} / \mathrm{ml}$ ) dissolved in distilled water, 0.33 $\mathrm{ml}$ of phosphate buffer (50 mM, $\mathrm{pH} 7.9)$, $0.1 \mathrm{ml}$ of ascorbic acid in sequence. The mixture was then incubated at $37^{\circ} \mathrm{C}$ for 1 hour. $1.0 \mathrm{ml}$ portion of the incubated mixture was mixed with $1.0 \mathrm{ml}$ of $10 \%$ TCA and 1.0 $\mathrm{ml}$ of $0.5 \%$ TBA (in $0.025 \mathrm{M} \mathrm{NaOH}$ containing $0.025 \%$ BHA) to develop the pink chromogen measured at 532nm. The hydroxyl radical scavenging activity of the extract is reported as \% inhibition of deoxyribose degradation is calculated by using the following equation:

$\%$ inhibition $=\frac{\text { control-test }}{\text { control }} X 100$

\section{ABTS Radical Scavenging activity}

ABTS radical scavenging activity was measured using an improved assay $(\operatorname{Re} e t$ al., 1999) [9]. The pre-formed radical monocation of 2,2'-azinobis-(3ethylbenzothiazoline-6-sulfonic acid) $\left(\mathrm{ABTS}^{+}\right.$) is generated by oxidation of ABTS with potassium persulfate and is reduced in the presence of such hydrogen-donating antioxidants. $20 \mathrm{mM}$ ABTS and $17 \mathrm{mM}$ potassium persulphate stock solutions were prepared. $0.3 \mathrm{ml}$ of potassium persulphate was added $50 \mathrm{ml}$ of ABTS and was left to stand overnight in dark before use. $1 \mathrm{ml}$ of distilled water $0.2 \mathrm{ml}$ of various concentration of the samples and $0.16 \mathrm{ml}$ of ABTS solution were mixed and made up to the final volume $1.36 \mathrm{ml}$. Absorbance was measured after $20 \mathrm{~min}$ at $734 \mathrm{~nm}$ and the percentage inhibition was calculated using the equation.

$$
\% \text { inhibition }=\frac{\text { control }- \text { test }}{\text { control }} X 100
$$

\section{Total antioxidant capacity}

The total antioxidant capacity of the extracts was evaluated by the phosphomolybdenum method according to the procedure described by Prieto et al., (1999) [10]. $0.3 \mathrm{ml}$ of extract was added to 3 $\mathrm{ml}$ of reagent solution $(0.6 \mathrm{M}$ sulphuric acid, $28 \mathrm{mM}$ sodium phosphate and $4 \mathrm{mM}$ ammonium molybdate). The tubes containing the reaction solution were incubated at $95^{\circ} \mathrm{C}$ for $90 \mathrm{~min}$ then, the absorbance of the solution was measured at $695 \mathrm{~nm}$ using a UVVIS spectrophotometer against blank after cooling down to room temperature. Methanol $(0.3 \mathrm{ml})$ in the place of extract was used as the blank. The total antioxidant activity is expressed as the number of gram equivalent of ascorbic acid. The calibration curve was prepared by mixing ascorbic acid with methanol. 


\section{Hepatoprotective effect of plant extracts in}

\section{HepG2 cell line}

The screening of hepatoprotective activity of A.vaginalis was based on the protection of human liver-derived HepG2 cell lines against $\mathrm{CCl}_{4}$-induced damage. HepG2 cells were obtained from National Centre for Cell Science, Pune, India. They are considered a good model to study toxicity in vitroto the liver since it retains many of the specialized functions which shows the characteristics of normal human hepatocytes [11] and retain many morphological characters of liver cells [12]. The cell line was cultured in DMEM supplemented with 10\% FBS, -L-glutamine, sodium bicarbonate and antibiotic solution containing: Penicillin $(100 \mu \mathrm{g} / \mathrm{ml})$, Streptomycin $(100 \mu \mathrm{g} / \mathrm{ml})$, and Amphotericin B $(2.5 \mu \mathrm{g} / \mathrm{ml})$ and kept at $37^{\circ} \mathrm{C}$ in a humidified $5 \% \mathrm{CO}_{2}$ incubator.

Confluent monolayer of cells were trypsinized and $100 \mu 1$ cell suspension $\left(5 \times 10^{4}\right.$ cell/well $)$ was seeded in 96 well tissue culture plate and incubated at $37^{\circ} \mathrm{C}$ in a humidified $5 \% \mathrm{CO}_{2}$ incubator. The cells after attaining sufficient growth were then exposed toCCl $\mathrm{Cl}_{4}(0.1 \%)$ and incubated for one hour;plant extracts in 5\%DMEM with different concentration $(100 \mu \mathrm{g}, 50 \mu \mathrm{g}, 25 \mu \mathrm{g}$, $12.5 \mu \mathrm{g} \& 6.25 \mu \mathrm{g}$ ) were added and incubated at $37^{\circ} \mathrm{C}$ in a humidified $5 \% \mathrm{CO}_{2}$ incubator.
No plant extract was added to the negative control. Cytotoxicity was assayed by estimating the viability of the HepG2 cells by the MTT reduction assay [13]. Supernatant was removed and $3 \mu 1$ of reconstituted MTT solution was added to all and then incubated at $37^{\circ} \mathrm{C}$ in a humidified $5 \% \mathrm{CO}_{2}$ incubator for 4 hours. The absorbance values were measured by using microplate reader at a wavelength of $570 \mathrm{~nm} \mathrm{[14]}$.

The percentage of growth inhibition was calculated using the formula:

$\%$ of Viability $=\frac{\text { Mean OD of Sample }}{\text { Mean OD of Control }} \times 100$

\section{Statistical analysis}

All data were represented as mean \pm SE of triplicates. Linear regression analysis in MS Excel 2013were carried out for in vitro cytotoxicity study. The $\mathrm{IC}_{50}$ value of free radical scavenging activity was calculated using probit analysis method using SPSS (version 19).

\section{RESULT AND DISCUSSION}

\section{In vitro cytotoxicity study}

In the present study, the effect of the three extracts of $A$. vaginalis on the percentage viability of L929 was evaluated (Figure 1). Of the three extracts, the high percentage viability is shown in the methanol extract when compared with the AVH and AVE at the highest concentration $(100 \mu \mathrm{g} / \mathrm{ml})$. From the linear regression analysis the $\mathrm{IC}_{50}$ values 
of the AVH, AVE \& AVM were calculated as $55.26, \quad 41.51$ and $112.61 \mu \mathrm{g} / \mathrm{ml}$, respectively (Table 1). Higher the $\mathrm{IC}_{50}$ values, lesser is the toxicity of the material [15]. $\mathrm{IC}_{50}$ value lesser than $100 \mu \mathrm{g} / \mathrm{ml}$ can be considered as moderately toxic. AVM shows higher $\mathrm{IC}_{50}$ value which can be considered as non-toxic. A similar report was given by the brine shrimp lethality assay. The toxicity of a compound can influence the normal activity of the cell [16].

\section{In vitro antioxidant activity}

Antioxidant activity in the present study were assessed by ABTS and hydroxyl radical scavenging assay. The ABTS and HO radical scavenging activities for all the extracts showed concentration dependent patterns, which is exhibited in Figure 2 and Figure 3. $\mathrm{IC}_{50}$ is the concentration which is required to scavenge 50\% free radical (Table 1). A low $\mathrm{IC}_{50}$ value shows a high antioxidant activity. AVE shows a high antioxidant activity with lowest $\mathrm{IC}_{50}$ value as $401.02 \pm 0.08$ and229.85 \pm 0.07 for ABTS and HO respectively, which is followed by AVM and AVH. Total antioxidant capacity of the AVH, AVE and AVM were found to be $145.1 \pm 1.9,153.97 \pm 0.89$ and $127.19 \pm 4.34$ mg Ascorbic Acid equivalent/g plant extract respectively which shows that AVE with highest antioxidant activity $[2,4]$.

\section{Hepatoprotective effect in HepG2 cell lines}

Liver damage induced by $\mathrm{CCl}_{4}$ is conventionally used model for the screening of hepatoprotective drugs [17]. $\mathrm{CCl}_{4}$ undergoes metabolic activation by a cytochrome P-450 dependent step to free radical products which can initiate lipid peroxidation. Many previous reports confirm the decrease of both toxicity and lipid peroxidation induced by $\mathrm{CCl}_{4}$ by many natural antioxidants [17, 19]. HepG2 cell lines has increasingly been used as a model to study the hepatoprotective action of natural antioxidants $[\mathbf{1 7}, \mathbf{1 9}, \mathbf{2 0}, \mathbf{2 1}]$. The hepatoprotective effect of the extracts of A.vaginalis was evaluated in HepG2 cell lines. HepG2 cell lines exposed to $\mathrm{CCl}_{4}$ showed a percentage viability of $29.6 \%$. These $\mathrm{CCl}_{4}$ exposed cells when treated with different concentrations of plant extract of A.vaginalis showed a dose - dependent increase in percentage viability in the case of AVM and AVH, while for AVE, the lower concentration showed a hepatoprotective activity which at higher concentrations produced an inhibitory effect. The highest hepatoprotective activity was seen in methanolic extract $(56.1 \mu \mathrm{g} / \mathrm{ml})$ than the hexane extract $(53.86 \mu \mathrm{g} / \mathrm{ml})$. High phenolic and flavonoid compounds present in the methanol extract was reported [16]. A high 
correlation between total phenolic content and the hepatoprotective activity was reported [20]. The high phenolic content of AVM gives the high hepatoprotective activity than the other two extracts. AVE showed high cytotoxic effect in L929 cell lines with low $\mathrm{IC}_{50}$ value. The compound of ethyl acetate extract that gives cytotoxic effects produce an inhibitory effect to the HepG2 cell lines under higher concentrations. Considering the different extracts of this plant, the methanolic fraction can be identified as the less toxic and it displayed good antioxidant activity with higher hepatoprotective activity. The antioxidative compound might be contributing the hepatoprotective effect against $\mathrm{CCl}_{4}$ induced toxicity. Therefore AVE under lower concentration and AVM $(100 \mu \mathrm{g} / \mathrm{ml})$ can be considered for further pharmacological evaluation (Figure 4).

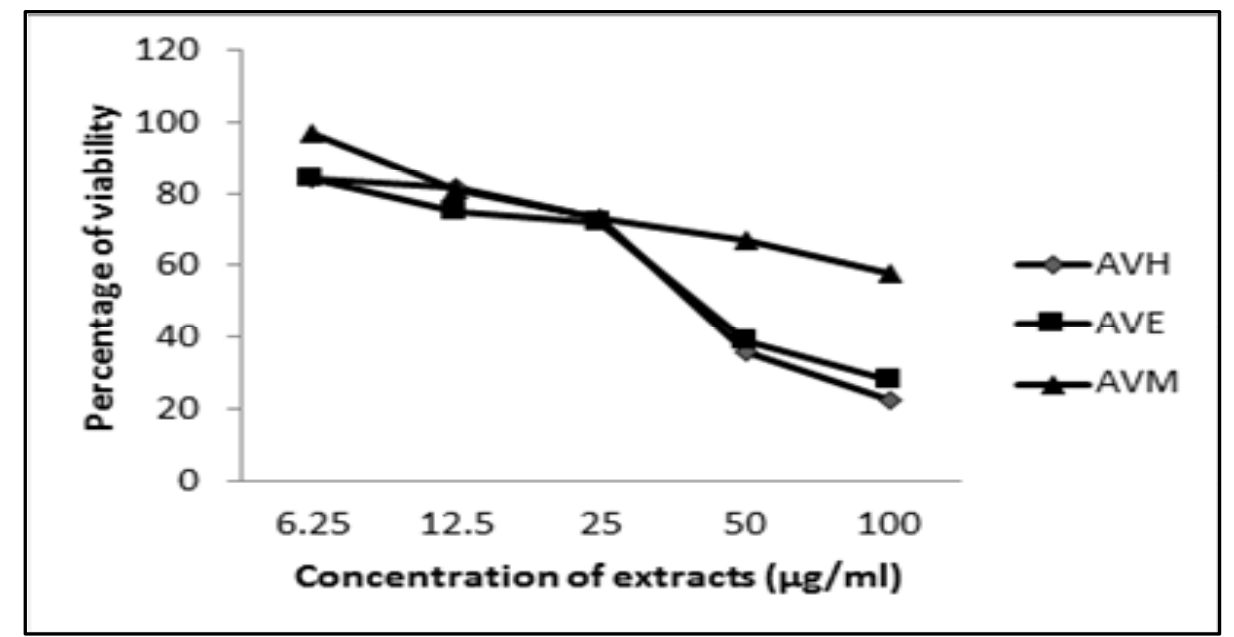

Figure 1: In vitro cytotoxicity effects of different extracts of A.vaginalis on L929 fibroblast cell lines

\begin{tabular}{|c|c|c|c|c|c|}
\hline Compound & $\begin{array}{c}\text { Invitro } \\
\text { cytotoxicity }\left(\mathrm{IC}_{50}\right. \\
\mu \mathrm{g} / \mathrm{ml})\end{array}$ & $\begin{array}{l}\text { Hydroxyl radical } \\
\quad\left(\mathrm{IC}_{50} \mu \mathrm{g} / \mathrm{ml}\right)\end{array}$ & $\begin{array}{c}\text { ABTS } \\
\left(\mathrm{IC}_{50} \mu \mathrm{g} / \mathrm{ml}\right)\end{array}$ & $\begin{array}{l}\text { Total Antioxidant } \\
\text { (mg AAE/g plant } \\
\text { extract) }\end{array}$ & $\begin{array}{l}\text { HepG2 Cells } \\
\left(\mathrm{EC}_{50} \mu \mathrm{g} / \mathrm{ml}\right)\end{array}$ \\
\hline AVH & 55.26 & $582 \pm 0.08$ & $877 \pm 0.08$ & $145.1 \pm 1.9$ & 78.44 \\
\hline AVE & 41.51 & $229.85 \pm 0.07$ & $401.02 \pm 0.08$ & $153.97 \pm 0.89$ & 12.32 \\
\hline AVM & 112.61 & $248.28 \pm 0.078$ & $431.02 \pm 0.08$ & $127.19 \pm 4.34$ & 53.38 \\
\hline L-Ascorbic Acid & & $314.87 \pm 0.07$ & $411.82 \pm 0.08$ & & \\
\hline
\end{tabular}

IJBPAS, January, 2021, 10(1) 


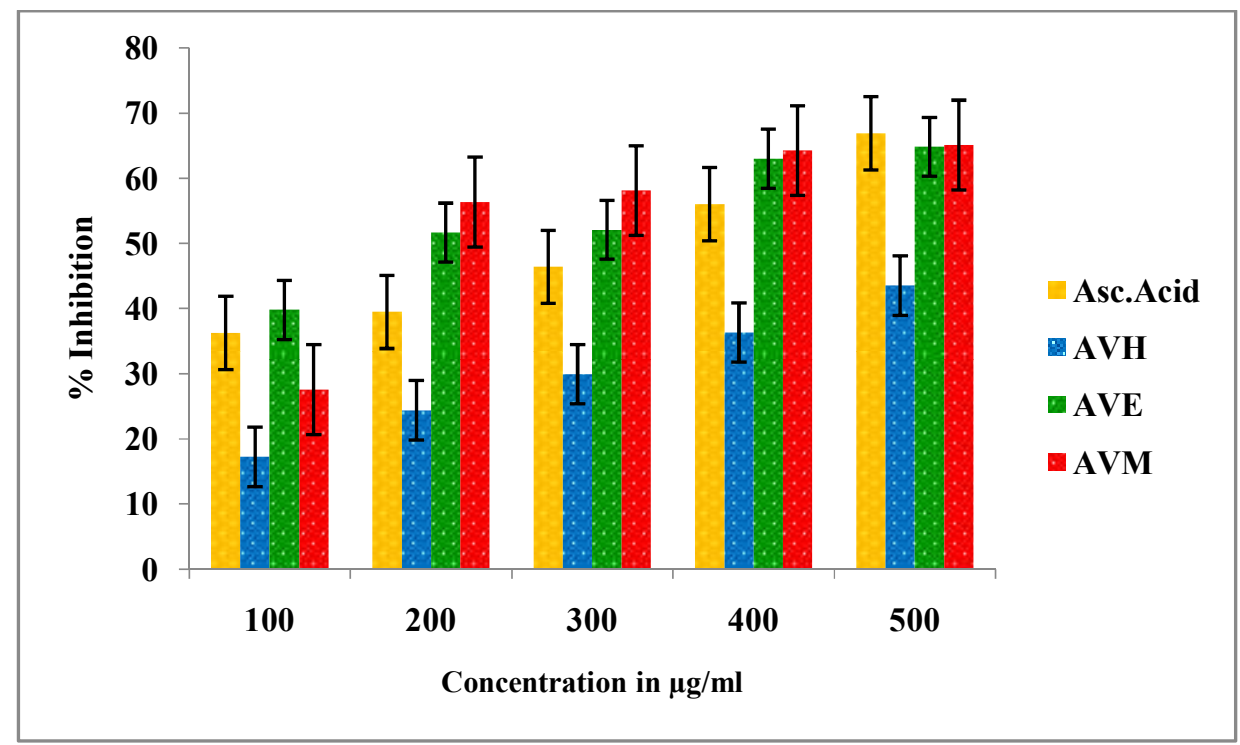

Figure 2: Hydroxyl radical scavenging activity of different extracts of Alysicarpus vaginalis Values are represented as mean \pm SEM of three replicates

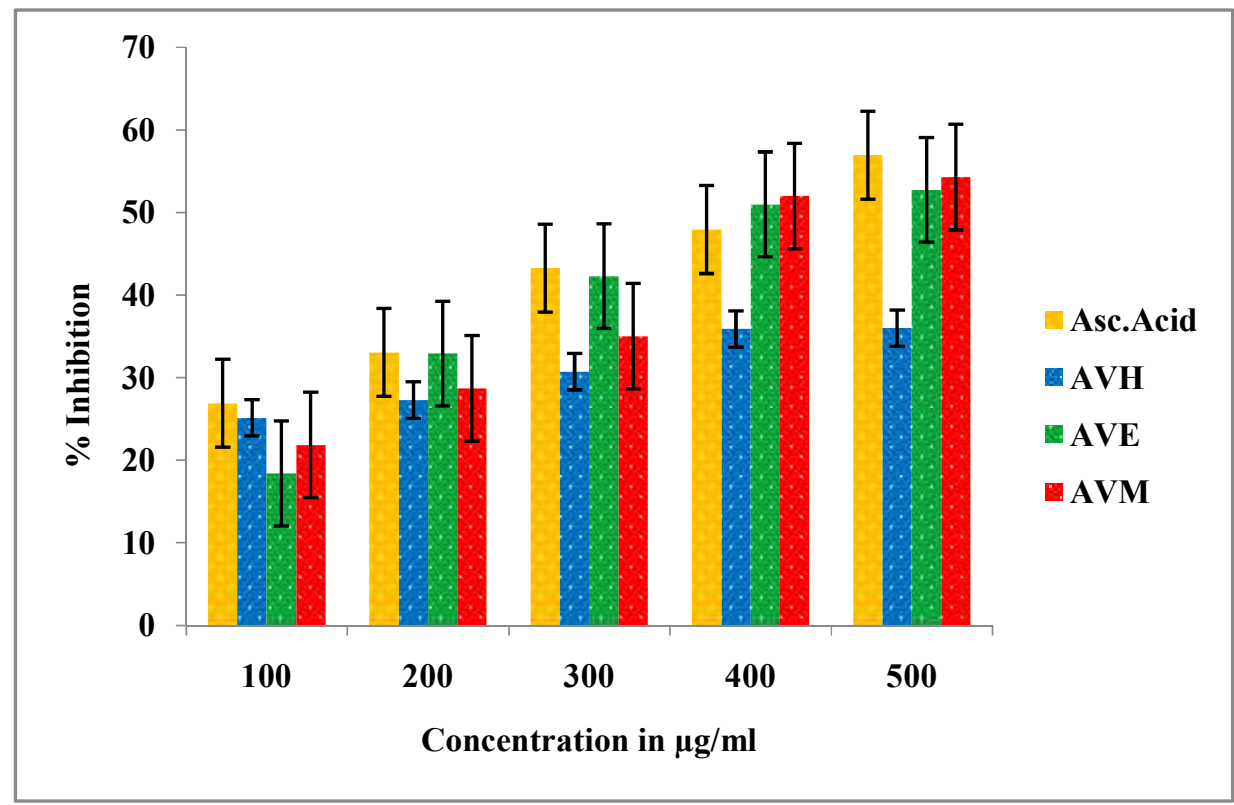

Figure 3: ABTS radical scavenging activity of different extracts of Alysicarpus vaginalis Values are represented as mean $\pm \mathrm{SEM}$ of three replicates 


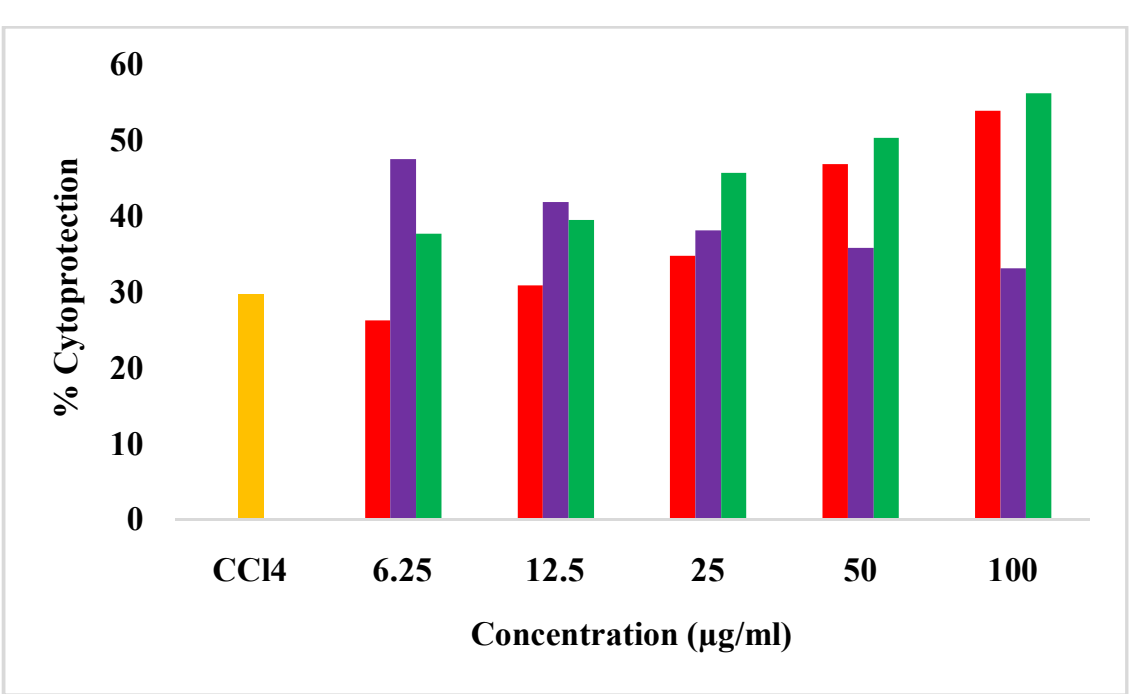

Figure 4: Hepatoprotective effect of hexane(AVH),ethyl acetate (AVE) and methanol (AVM) extract of A. vaginalis against $\mathrm{CCl}_{4}$ induced toxicity

\section{CONCLUSION}

The present study reported the invitro cytotoxicity effect of the successive extracts of A.vaginalis on L929 cell lines. The methanol extract (AVM) showed the least cytotoxic effect. The invitro antioxidant activities of the plant extracts were evaluated. AVM showed a high antioxidant activity followed by AVE and AVH. Oxidative stress was introduced in HepG2 cell lines by $\mathrm{CCl}_{4}$ toxication. The cell viability was improved with the treatment of the extracts of A.vaginalis. AVM had the less cytotoxic effect with high antioxidant and hepatoprotective activity which is followed by AVE and AVH. The occurrence of antioxidative principles and hepatoprotective action of this plant extracts support its ethanopharmacological use for the treatment of hepatitis. Further efforts are needed for the isolation and characterization of the bioactive compound and the in vivo studies can reveal the mechanism of the action of these plant extracts.

\section{ACKNOWLEDGEMENT}

The authors wish to thank the Principal, Mar Ivanios College, Thiruvananthapuram, Kerala, for providing the necessary facilities to do the work. The financial support from the University Grand Commission in the form of Teacher Fellowship under the Faculty Development Programme (No.FIP/12 ${ }^{\text {th }}$ Plan/KLKE013 TF- $08 \mathrm{dt}$. $09 / 02 / 2016$ ) to the first author is gratefully acknowledged.

\section{REFERENCES}

[1] Patel R M and Patel S K, Cytotoxic activity of methanolic extract of Artocarpus heterophyllus against 
A549, Hela and MCF-7 cell lines, $J$ App Pharm Sci, 2011, 01 (07), 167171.

[2] Tarun G and Pindi P K, Evaluation of antioxidant potential and antimicrobial activity of successive extracts of Pimpinella tirupatiensis. $J$ pharm Res. 2013, 7,817-822.

[3] Saraf Swarnalatha and Aswath M S, Flavanoids, a nutritional protection against oxidative and UV induced cellular damages, Pharmacogn Rev, 2000, 1(1), 30-40.

[4] Arulappa R X and Ilango K, In Vitro Antioxidant Study of Extracts of Tephrosia spinosa (L.F) Pers. Int $J$ Res Pharm Bio Sci, 2013, 4(1), 239242.

[5] Senthilraja P and Kathiresan K, In vitro cytotoxicity MTT assay in Vero, HepG2 and MCF -7 cell lines study of Marine Yeast, J App Pharm Sci, 2015,5 (3), 80-84.

[6] Duke J A, Handbook of legumes of world economic importance, New York, USA: Plenum Press, 1981,345.

[7] Harborne J B, Phytochemical methods, 2nd edition. Chapman and Hall publications, London, New York, 1984, 288.
[8] Halliwell B, Free radicals, antioxidants, and human disease: Curiosity, cause, or consequence? Lancet, 1994, 344, 721-724.

[9] Re R, Pellegrini N, Proteggente A, Pannala A, Yang $M$ and Rice-Evans $\mathrm{C}$, Antioxidant activity applying an improved ABTS radical cation decolorization assay, Free RadBiol Med, 1999, 26(9-10), 1231-1237.

[10] Prieto P, Pineda $M$ and Aguilar M, Spectrophotometric quantification of antioxidant capacity through the formation of a phosphomolybdenum complex: specific application of vitamin E, Anal Biochem, 1999, 269, 337-341.

[11] Knasmuller S, Parzefall W, Sanyal R, Ecker S, Ecker S, Schwab C, Uhl M, Mersch Sundermann V, Williamson G, Hietch G, Langer T, Darroudi F, Natarajan A T, Use of metabolically competent human hepatoma cells for the detection of mutagens and antimutagens, Mutat Res, 1998, 402,185-202.

[12] Knowles B B, CC Howe, and D P Aden, Human hepatocellular carcinoma cell lines secrete the major plasma proteins and hepatitis 
B surface antigen. Science, 1980, 209,497-499.

[13] Vasanth P R, Raghu H, Chandrashekhar, Vijayan P, Dharmaraj S A, Mallikarjuna C, Venkata J. Rao Nitash K, Invitro and invivo hepatoprotective effects of total alkaloid fractions of Hydrophila auriculata leaves, Indian J Pharmacol, 2010,42(2), 99104.

[14] Talarico Laura B, Zibetti Rosiane G M, Faria Paula C S, Scolaro Luis A, Duarte Maria E R, Noseda Miguel D, Pujol Carlos A, et al., Antiherpes simplex virus activity of sulfated galactans from the red seaweeds Gymnogongrus griffithsiae and Cryptonemia crenulata, Inter $J$ of biological macromolecules, 2004, 34(1-2), 63-71.

[15] George M, Josekumar V S. In vitro cytotoxicity screening, phytochemical profile and heavy metal analysis of different extracts of Acrosticum heterophyllum L. Indian J Nat Prod Resour. 2016, 7, 19-24.

[16] Kurian S and Josekumar V S, Phytochemical screening, antimicrobial activity and brine shrimp lethality bioassay of different extracts of Alysicarpus vaginalis var. nummularifolius (DC.) Miq. (Family: Fabaceae), Int $J$ Pharm Pharm Sci, 2017, 9(1), 83-86.

[17] Krithika R, Rasamony Mohan kumar, Ramtej J Verma, Pranav S S, Illiyas L M, Gunasekaran P, Srinivasan N, Isolation, characterization and antioxidant effect of phyllanthin against $\mathrm{CCl}_{4}$-induced toxicity in HepG2 cell lines, Chemico-Biological Interactions, 2009, 181, 351-358.

[18] Ko K M, Yick K P, Chiu T W, Impaired hepatic antioxidant status in $\mathrm{CCl}_{4}$ intoxicated rats as in vivo model for screening herbal extracts with antioxidant activities, Fitoterapia, 1993, 64, 539-544.

[19] Thabrew M I, Robind D H and Lan G Mcfarlane, Screening of hepatoprotective plant products using a HepG2 cell cytotoxicity assay, J Pharm Pharmacol, 1997, 49, 1132-1135.

[20] Akanitapichat P, Kallayanee P, Kwunchai N, Suparichart Prompitakkul, Antioxidant and hepatoprotective activities of five eggplant varieties, Food and chemical toxicology, 2010, 48, 3017-3021. 
[21] Oh H, Do-Hoon Kim, Jung-Hee Cho and Youn-Chul Kim, Hepatoprotective and free radical scavenging activities of phenolic petrosins and flavonoids isolated from Equisetum arvense, $J$ of Ethanopharmacology, 2004, 95, 421-424.

[22] Boll M, Weber L W, Becker E, Stampfl A, Mechanism of $\mathrm{CCl}_{4}$ induced hepatotoxicity. Hepatocellular damage by the reactive $\mathrm{CCl}_{4}$ metabolites, Z Naturforsch, 2001, 26, 649-659.

[23] Moya M A, Ramos S, Mateos R, Granado Serrano A B, Izquierdo Pulido M, Bravo L, Goya L, Protection of human HepG2 cells against oxidative stress by cocoa phenolic extract, J Agri Food Chem, 2008, 56, 7765-7772. 